\title{
Research Square \\ Nitrate modulation of Bacillus sp. biofilm components: a proposed model for sustainable bioremediation
}

Ola Gomaa ( $D$ ola_gomaa@hotmail.com )

Egyptian Atomic Energy Authority https://orcid.org/0000-0002-0591-2258

Hussein Abd E EL Kareem

Egyptian Atomic Energy Authority

Nabila Selim

Egyptian Atomic Energy Authority

\section{Research Article}

Keywords: Nitrate, Bacillus sp., biofilm, EPS, sustainable bioremediation, structural biology

Posted Date: June 14th, 2021

DOI: https://doi.org/10.21203/rs.3.rs-596617/v1

License: (1) This work is licensed under a Creative Commons Attribution 4.0 International License.

Read Full License

Version of Record: A version of this preprint was published at Biotechnology Letters on September 12th, 2021. See the published version at https://doi.org/10.1007/s10529-021-03185-z. 


\section{Abstract}

The presence of different pollutants in wastewater hinder microbial growth, compromise enzymatic activity or compete for electrons required for bioremediation pathway. Therefore, there is a need to use a single microorganism that is capable of tolerating different toxic compounds and can perform simultaneous bioremediation. In the present study, nitrate reducing bacteria capable of decolorizing azo dye was identified as Bacillus subtillis sp. DN using Protein profiling, morphological and biochemical tests X-ray diffraction pattern, Raman spectroscopy and cyclic voltammetry confirm that the bacterium under study possesses membrane-bound nitrate reductase and that is capable of direct electron transfer. The addition of nitrate concentrations $(0-50 \mathrm{mM})$ resulted in increased biofilm formation with variable exopolysaccharides (EPS), protein, and eDNA. Fourier Transform Infrared spectrum revealed the presence of a biopolymer at high nitrate concentrations. Effective capacitance and conductivity of the cells grown in different nitrate concentrations suggest changes in the relative position of polar groups, their relative orientation and permeability of cell membrane as detected by dielectric spectroscopy. The increase in biofilm shifted the removal of the azo dye from biodegradation to bioadsorption. Our results indicate that nitrate modulates biofilm components. Bacillus sp. DN granular biofilm can be used for simultaneous nitrate and azo dye removal from wastewater.

\section{Introduction}

Azo dyes present one of the dangerous synthetic compounds that are widely used commercially. The discharge of azo dye containing water poses a threat both to human and aquatic life (Solanki et al. 2017). Treatment of colored wastewater can be performed using physical, chemical, or biological treatment, the latter is considered efficient and cheap as compared to the first two methods. While biological treatment is indeed more practical and environmentally safe, the presence of different pollutants in the wastewater is expected to compromise microbial cell viability and functionality of the bacterial degradation system. The increasing complexity of wastewater treatment over the past decades due to the presence of co-pollutants such as nitrogenous, carbonaceous, and phosphorous compounds (Sarkar et al. 2010). Nitrates presence in colored wastewater results in the competition since both nitrates and azo dyes are electron acceptors. Azo dye reduction was reported to take place after the denitrification of the wastewater was completed (Cirik et al. 2013). In the present work, we will focus on the co-presence of nitrates and azo dyes and enhance their simultaneous removal using Bacillus sp. granular biofilm.

Bacillus sp. are reported to possess a large nitrification and denitrification gene inventory and dissimilatory nitrate/nitrite reduction to ammonia (DNRA), it has membrane-bound denitrification and periplasmic nitrate reductase (Sun et al. 2016). Given this potential along with its ability to grow in biofilms, its use as biofilm granules provides a potential for a sustainable bioremediation process. Bacillus subtilis biofilm was reported to consist of 1) polysaccharide moiety encoded by epsA and epsO genes and is responsible for adhesion, stability, and scaffolding, 2) surface protein moiety that is encoded by BsIA gene and is responsible for hydrophobicity, scaffolding, and cell-to-cell binding. In addition to polysaccharides and proteins, all bacteria have eDNA that is responsible for adhesion, 
cohesion, nutrient source, damage repair, gene transfer, and interaction with other matrix components and lipids that are also responsible for adhesion, cohesion, and protection of cells within the biofilm (Karygianni et al. 2020).

Biofilms, flocs, and granular bacterial forms have been investigated for the removal of pollutants and nutrients. Bioaggregation into any of these forms provides structure and stability for the bacteria and protects it from pollutants (Aqeel et al. 2019). Biofilm granules were used as oxygenic photgranules (OPGs) form for wastewater treatment (Stauch-White et al. 2017). Biofilm seed carriers provided an easy and quick starting up seed in an annamox moving bed biofilm reactor (MBBR) (Kowalski et al. 2018).

The presence of nitrates have been correlated with granular biofilm formation for wastewater treatment (Stauch-White et al. 2017) and since nitrate present in textile wastewater comes from salts used in dye fixation )Cirik et al. 2013), or from domestic wastewater leaching to the same tank, our idea was to induce biofilm formation as an initial step before azo dye reduction. Our understanding of the mechanism of formation and structural changes in biofilms would help in creating conditions that favor the removal of pollutants. From this standpoint, the present work aims to study the impact of nitrate on biofilm components of Bacillus sp., study the biochemical and biophysical changes that took place in nitrate containing media, and propose a model for sustainable bioremediation of nitrate co-polluted colored wastewater.

\section{Materials And Methods}

\section{Isolation, characterization, and identification of nitrate reducing bacteria}

Enrichment media was used to isolate a nitrate reducing bacteria. The water sample was kindly provided by Ass. Prof. Mohamed Refaat El Shahawy, Rad Microbiology Dept (NCRRT). The sample was collected from a pond near Agiba petroleum company oil fields, Marsa Matrouh Governorate. The enrichment media was composed of $(\mathrm{g} / \mathrm{l}) 0.5(\mathrm{NH} 4)_{2} \mathrm{SO} 4,0.36 \mathrm{KNO}_{3}, 4 \mathrm{NaNO}_{3}, 0.05 \%$ trace element solution. $\mathrm{pH}$ was adjusted to 7. Denitrifying media was composed of (g/l) 5 sodium acetate, $1 \mathrm{NaNO}_{3}, 2 \mathrm{~K}_{2} \mathrm{HPO}_{4}, 0.5 \mathrm{NaCl}$, $0.2 \mathrm{MgSO}_{4} \cdot 7 \mathrm{H}_{2} \mathrm{O} . \mathrm{pH}$ was adjusted to 7 (Shao et al. 2019). The isolate showing the tolerance to nitrate and decolorization was characterized according to Bergey's manual of determinative bacteriology. Detection of biofilm was performed using Congo red agar (CRA) method. Brain heart infusion broth (BHI) was prepared according to the manufacturer's instructions (Oxoid, UK). Colonies turning black were regarded as biofilm forming whereas those remaining white to pinkish were considered biofilm negative. Biochemical tests were performed according to Bergy's manual. The isolate was further identified using Matrix-assisted laser desorption ionization-time of flight mass spectrometry (MALDI-TOF MS) mass spectra were acquired by Microflex MALDI-TOF MS (Bruker Daltonics, Bremen, Germany) (Scientific Services). MALDI BioTyper 2.0 software was used for analysis and comparison with the MALDI BioTyper database.

\section{X-Ray Diffraction (XRD)}


Bacteria were grown for $24 \mathrm{~h}$ in LB media at $37^{\circ} \mathrm{C}$ and were centrifuged, washed with phosphate buffer, and dried at ambient temperature for $24 \mathrm{~h}$. XRD patterns were recorded on a Shimadzu diffractometer XDD1 X-ray diffraction spectrometer with a copper target at an operating voltage of $40 \mathrm{kV}$ and an electric current of $30 \mathrm{~mA}$.

\section{Raman imaging}

Bacteria were grown for $24 \mathrm{~h}$ in LB media at $37^{\circ} \mathrm{C}$ and were centrifuged, washed with phosphate buffer, and dried at ambient temperature for $24 \mathrm{~h}$. The dried sample was scanned using Confocal laser microraman microscope WITEC Focus Innovation Alpha 3000, Germany. The sample was excited using a laser beam at $532 \mathrm{~nm}$ and collected in the $30-3000 \mathrm{~cm}^{-1}$ region at $15 \mathrm{~mW}$ for $5 \mathrm{sec} \times 20$. Image was collected using CCD camera.

\section{Oxidation Reduction Reaction (ORR)}

Cyclic voltammetry (CV) was used to identify the oxidation reduction reaction (ORR) of Bacillus sp. in the presence of different nitrate concentrations. The electrodes were tested at scan rate $50 \mathrm{mV} / \mathrm{s}$. The 3electrode set up consisted of 24h grown cells, $0,0.1,0.25,0.5$ and $1 \mathrm{~g} / \mathrm{I} \mathrm{NaNO3}$ were added to cell. Carbon rod was used as working electrode, Pt electrode as a counter electrode and an $\mathrm{Ag} / \mathrm{AgCl}$ (saturated $\mathrm{KCl}$ ) as a reference electrode. Electrodes were connected to BioLogic science instruments Potentiostat/Galvanostat (Germany) at NCRRT. The electrochemical cell was sealed and gassed with nitrogen to ensure an anaerobic environment during the experiment. To determine catalytic activity and electroactivity of bacterial biofilm, cyclic voltammetry was measured in the potential region between - 0.7 $+0.1 \mathrm{~V}$ vs $\mathrm{Ag} / \mathrm{AgCl}$. , Scan rate $50 \mathrm{mV} / \mathrm{s}$.

\section{Biochemical changes in Bacillus sp. cells exposed to different nitrate concentration}

Bacillus sp. was incubated with different volumes of nitrates $(0,6,12,25$ and $50 \mathrm{mM})$, the number of colony forming units $(\mathrm{CFU} / \mathrm{ml})$ was obtained from the appropriate dilution and log count was calculated and plotted. Biofilm formation was detected using crystal violet method described by Allkja et al. (2020), the changes in the density of the biofilm were followed using ELIZA reader at NCRRT, readings were taken at $595 \mathrm{~nm}$ in 96 well round bottom plate. Concavalin dye was used to measure EPS, methylene blue was used to measure protein (Liu et al. 2010) and ethidium bromide was used to detect eDNA (lyer et al. 2012) in samples grown under different nitrate concentrations. Readings were taken using TECAN Spark multimode reader at NCRRT.

\section{Scanning Electron Microscopy (SEM)}

Scanning electron micrographs of the isolated bacteria were captured using a JOEL JMS 5600 scanning electron microscope, cells were centrifuged and fixed using different alcohol concentrations and placed to dry on glass cover slip for $24 \mathrm{~h}$. A suitable piece was cut using a clean sterile cutter then glued onto brass stub using a double-sided adhesive tape and was coated with a thin layer of gold under reduced 
pressure. The images were captured at magnifications of $7500 \mathrm{X}$ using an electron beam high voltage of $30 \mathrm{kV}$.

\section{Fourier Transform Infrared Spectroscopy (FT-IR):}

Fourier Transform Infrared Spectroscopy (FT-IR) was used to detect vibrational frequency changes of bacteria grown under different nitrate concentration. The obtained spectra represent the peaks for functional groups of the samples. Scanning was performed from 400 to $4000 \mathrm{~nm}$ using ATR-FTIR, BRUKER VERTEX 70 device at NCRRT. The analytical spectrum was then compared to library to identify the functional groups.

\section{Dielectric properties}

The biophysical changes were assayed using dielectric measurements as described before (Gomaa et al. 2013). The bacterium was grown in LB supplemented with different nitrate concentrations $(0,5,12,25$ and $50 \mathrm{mM}$ ) for $24 \mathrm{~h}$ at $37^{\circ} \mathrm{C}$ under static conditions. The cells were harvested by centrifugation at 6000 rpm for $15 \mathrm{~min}$, washed twice with phosphate buffer saline $(\mathrm{pH} 7)$ and suspended in $50 \mathrm{ml}$ distilled water for dielectric measurements which were carried out over the frequency range of $40 \mathrm{kHz}$ to $1 \mathrm{MHz}$ using LCR meter type HIOKI 3531, manufactured in Japan. The measured parameters are capacitance (C) and conductance $(G)$. The relative permittivity $\varepsilon^{\prime}$, dielectric loss $\varepsilon^{\prime \prime}$, area under loss peak and effective capacitance $\left(\mathrm{C}_{\text {eff }}\right)$ of the bacterial cells, were calculated as previously discussed (Selim et al. 2010).

\section{Bioremoval of Congo red dye}

Congo red dye was added at initial concentration of $50 \mathrm{mg} / \mathrm{l}$. Decolorization was followed at $497 \mathrm{~nm}$ after 4 days at $37^{\circ} \mathrm{C}$ under microaerophilic conditions. Decolourization was calculated using the following equation at:

\section{Decolorization $(\%)=\frac{I-F}{F} \times 100$}

Where I indicates the initial colour and $\mathrm{F}$ the absorbance at the end of the decolorization process. Adsorptive capacity of bacteria to congo red its efficacy was tested using different nitrate concentration. Initial and residual dye concentrations were measured as previously described. The adsorptive capacity was calculated by the following equation:

\section{Adsorptive capacity $\left(\mathrm{q}_{\mathrm{c})}\right)=\left(\frac{C i-C f}{W}\right) \mathrm{V}$}

Where $\mathrm{Ci}$ is the initial concentration, $\mathrm{Cf}$ is the final concentration, $\mathrm{W}$ is the weight of the bacteria after incubation with different nitrate concentrations (adsorbent) in $\mathrm{gm}, \mathrm{V}$ is the volume of the sample. The data presented are the mean value of three triplicate experiments with $3 \%$ error. 


\section{Biofilm granule formation}

Bacterial cell suspension supplemented with optimal nitrate concentration were left to incubate with sterile granular activated carbon granules (size 200) for $24 \mathrm{~h}$. The ACG were then carefully removed and left to dry overnight $50^{\circ} \mathrm{C}$ and were used for SEM imaging to confirm cell attachment and biofilm formation.

\section{Statistical analysis}

All experimental data indicated on the graphs and tables represent the mean value of triplicate experiments; the error bars in the graphs represent the standard deviation of the mean (SD). Statistical analysis of the data was conducted by one-way analysis of variance (ANOVA) using Microsoft Excel statistics package.

\section{Results And Discussion}

\section{Isolation, characterization and Identification of nitrate reducing bacteria}

The bacterial colonies grown under nitrate supplemented media were selected for purification, identification and characterization. The isolate was identified using MALDI-TOF-MS as Bacillus subtilis ssp. subtilis DSM 10 with 2.12 score which is interpreted as high confidence, NCBI identifier 135461. The Bacillus morphology identification, Mass Spectra and biochemical identification are reported in supplementary material (S1). This bacteria showed red and dry colonies on Congo red media which confirms the presence of fimbriae and indicates it has the ability to form biofilm. Structural

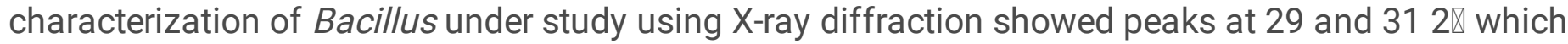
represents Fe-S and Mo (Fig. 1). Full Raman spectroscopy showed peaks at753, 1129, 1314 and 1583 $\mathrm{cm}^{-1}$ which correspond to cytochrome $\mathrm{c}$ subunit (Fig. 2), both suggest that this bacterium possess cofactors for NaR subunits.XRD and Raman spectroscopy can be used to characterize bacteria in single and biofilm forms, they provide a fast non-invasive technique for structural identification (Remoundak et al. 2007, Strola et al. 2014). The obtained results of XRD and raman spectroscopy confirm that a nitrate reductase enzyme complex is located in the outer membrane of Bacillus sp DN, this nitrate reductase consists of Mo cofactor as the alpha subunit, Fe-S cluster as the beta subunit, both are anchored to a heme containing cytochrome which represents the gamma subunit. The later receives electrons from a quinone pool and transfers them to the beta subunit and then to the electron acceptor (Coehlo et al. 2015). A previous study reported the structural shape of the membrane bound nitrate reductase heterotrimer as a "flower" (Balsco et al. 2001).

In order to confirm the electron transfer mechanism, cyclic voltammetry was used. The bacterium under study showed redox activities as indicated by the presence of anodic peaks at $0.18 \mathrm{~mA}$ and cathodic peak at $-0.35 \mathrm{~mA}$ for the bacteria in PBS, while 2 anodic peaks were observed at 0.11 and $0.085 \mathrm{~mA}$ and cathodic peak of $-00.114 \mathrm{~mA}$ when the bacterial culture filtrate was added to the bacteria (Fig.

3a). Electrochemical impedance spectroscopy (EIS) showed that the activation resistance $\left(R_{c t}\right)$ of the 
biofilm of the bacteria in the presence of the bacterial culture filtrate was less than that for the bacteria alone(Fig. 3b). This result confirms that Bacillus sp. DN possesses bacterial electron transfer mechanisms that depend on direct attachment to a substrate, this contact dependent mechanism is attributed to the multiheme cytochrome c proteins (MHCs) that shuttles electrons from the electron transport chain to the insoluble electron acceptor. This result is in agreement with Wringhton et al. (2011), Pankratova et al. (2018), Paquete (2020) who reported direct electron transfer in gram positive bacteria. In addition to the direct electron transfer, the presence of a soluble mediator in the media might have been the reason behind the second anodic peak and the decrease in activation resistance.

\section{Biochemical and structural changes of Bacillus sp. in the presence of different nitrate concentrations}

Fig. 4 represents the effect of nitrate on Bacillus sp. biofilm and three of its major components, EPS, proteins and eDNA. The biofilm components were stained using fluorescence dyes and were followed as fluorescence intensity. The use of concavalin A was used to identify carbohydrate moiety of the biofilm, this biofilm component showed an increase in the presence of nitrate that reached 2.16 fold when $12 \mathrm{mM}$ nitrate were added to the media, however, the concavalin A decreased again at nitrate concentrations above that. Concavalin $A$ is a fluorescent conjugate that binds with carbohydrate moiety, specifically glycoprotein (Drake et al 2006). This indicates that glycoprotein in the biofilms was affected by the nitrate concentration during biofilm formation. Methylene blue was used to follow the protein content (Liu et al 2010) as another biofilm component, the results showed an increase in protein that reached about 1.6 fold when the highest nitrate concentration was used. Ethidium bromide was used to detect the eDNA content in the biofilm in response to the nitrate concentrations used, the results showed almost no change in eDNA. (lyer et al. 2012) described their work that eDNA and other components contribute to the formation of biofilm. On the other hand, when crystal violet was used to detect the overall biofilm, the crystal binding to biofilm increased and reached 2.5 fold when $50 \mathrm{mM}$ nitrate was added. This result indicates that there is another component in the biofilm that was not detected using the abovementioned fluorescence dyes but is present and participates in the biofilm formation of the Bacillus sp. in the presence of nitrate. Shao et al. (2019) reported variation in polysaccharide and protein ratios of extracellular polymeric substances during a nitrification process. This confirms that nitrate presence modulates biofilm components.

SEM images shown in Fig. 5 represent all the samples at 2 magnifications, 750X and 5000X. The images reflect an increase in matrix binding the cells together, this matrix increases with the increase in nitrate concentration, consolidating the crystal violet result in Fig. 4.

The structural changes that took place when Bacillus sp. DN under study was incubated with different nitrate concentrations are shown in Fig. 6. FTIR spectra showed increased peaks as the concentration of nitrate increased, the evident peaks at $3247,2972 \mathrm{~cm}^{-1}$ belong to $\mathrm{CH}_{2}$ and $\mathrm{CH}_{3}$ stretching, peak at $1735 \mathrm{~cm}^{-1}$ belongs to ester carbonyl bond, while peaks located in the range from 1650 to $1000 \mathrm{~cm}^{-1}$ belong to carbohydrate. A glucan or glycan, peak at $1542 \mathrm{~cm}^{-1}$ belong to protein in carbohydrate. Peaks in fingerprinting region below $1000 \mathrm{~cm}^{-1}$ belong to nucleic acids (Gieroba et al. 2020). The results indicate 
that a surface bound glycoprotein is present. The glycoproteins were reported as responsible for cell-cell recognition. The FTIR fingerprint for EPS highly resembles that obtained by Saravanan and Jayachandran (2008) except the peak at $1735 \mathrm{~cm}^{-1}$ that represents the ester carbonyl bond indicates the presence of para hydroxyl-butyrate compound (Tugarova et al. 2017).

The media components and addition of some compounds can affect the structural biofilm development (Pamp and Neilsen 2007). Nitrate in specific is very ubiquitous, it has been known to inhibit biofilm formation in Burkholderia pseudomallei, nitrate inhibited the secondary signaling compound c-diGMP which affected the biofilm formation through a signaling process through a nitrate transporter, Nar-K1 (Mangalea et al. 2017). This indicates that nitrate acts as a signaling molecule. An association between nitrate reduction and biofilm extracellular matrix was established in bacteria colonizing urinary tract highlighting the role of NarL, a response regulator in modulating the biofilm regulator CsgD in Escherichia coli (Martín-Rodríguez et al. 2020). Despite that the abovementioned information is for bacteria different than the one under study, yet it proves that nitrate can act as a signal transducer in Bacillus as well since Bacillus possesses a two-component system (Fabret et al. 1999) and this is what they all have in common.

\section{Biophysical changes of Bacillus sp. in the presence of different nitrate concentrations}

The cells are surrounded by cell wall with different layers each with different compositions and porous structure to allow exchange small molecules with their surroundings. The cell wall contains large amounts of polysaccharides and other natural polymers, which are charged groups that give the wall their electrical properties (Markx \& Davey1999). The dielectric properties of cells' suspension represent a tool to investigate the behaviour of the membrane as a whole under different treatment conditions. They can provide a description through membrane conductivity and membrane permittivity about the dynamic and steric properties of membrane structure. These two parameters (membrane conductivity and permittivity) are important in investigating any occurring modifications in the overall membrane structure as a results of external treatment. The relative permittivity decreases as a function of frequency giving the well-known dispersion curve. The dielectric loss factor expresses the rate of conversion of electric energy to heat in the sample and appears as guassian curve all over the frequency range considered in this study. The area under the loss curve is proportional to the total concentration of dipoles in the material (Pethig, 1979). The relative permittivity, dielectric loss and conductivity at $1 \mathrm{kHz}$ decreased from the control sample for 6,12 and $25 \mathrm{mM}$ nitrate concentration, then increase as the nitrate concentration increased to $50 \mathrm{mM}$ (Fig. $7 \mathrm{a}, \mathrm{b}$ and c). The capacitance determines the amount of charge that can be stored across the membrane when the cell is exposed to an electric field, and depends strongly on the structure of cell wall and membrane. Each subunit of these structures acts as capacitor, their effective capacitance $\left(\mathrm{C}_{\text {eff }}\right)$ is determined by their relative positions. The response of the cell membrane to different concentration of nitrate treatment varies according to the nitrate concentration. In this study the effective capacitance $\left(\mathrm{C}_{\text {eff }}\right)$ showed decrease as the nitrate concentration increase up to $12 \mathrm{mM}$, and then increase to reach 3.8 fold the control value for the $50 \mathrm{mM}$ nitrate concentration as shown in Fig. $7 \mathrm{~d}$. 


\section{The effect of nitrate on the decolorization of congo red}

The choice of this strain was based on its ability to form biofilms, decolorize dyes in the presence of nitrate. The presence of nitrates affected the decolorization of congo red by Bacillus under study. Results in Fig. 8 shows that the ratio of biodegradation to adsorption was 80:20 in the absence of nitrates and $75: 25$ in the presence of $6 \mathrm{mM}$ nitrates but shifted to $50: 50$ at 12, 25 and $50 \mathrm{mM}$ nitrate concentration. The results show that azo reduction is at its best at low nitrate concentrations, whereas high nitrate concentrations affected the biodegradation, this result is in agreement with Cirik et al. (2013) who reported an adverse effect on azo dye reduction at high nitrate concentrations. Competition between nitrate and another electron acceptor compound such as azo dyes have been reported (Gomaa et al. 2017). The same competition was reported for a co-polluted media containing nitrate and perchlorate suggesting that nitrate has a lower energy barrier for proton and electron transfer (Lv et al. 2020). This electron competition affects the biodegradation performance of the bacteria. In the present study, this competition was compensated with an increase in biofilm formation that varied in thickness and components, providing functional groups that act as an adsorptive matrix, making, at the end, the treated wastewater clear.

\section{Proposed model for sustainable bioremediation}

Fig. 9 represents the SEM images of Bacillus sp DN growing on carbon granules and glass beads in the presence and absence of nitrates. The images show that the cells can form granular biofilm using $12 \mathrm{mM}$ nitrate which was optimal for production of EPS (Fig. 4). EPS has been reported to be responsible for facilitating cell adhesion and cell-cell recognition for biofilm formation.

Biofilms are known to form with a thickness, the structure of the biofilm usually consist of 1) distal region which is the outer layer and its exposed to oxygen, and is suitable for nitrate reduction 2) medial bulk region which has less oxygen and can be termed anoxic, it is very suitable for microaerophilic dye decolorization and 3) proximal region which is located closest to the substrate on which the biofilm grows, the latter is anaerobic and is very suitable for butyrate or any other SCFA production or biopolymer (such as PHB), and would provide energy source for bacterial cells. This configuration of bacterial growth in the 3 layers would make the same bacteria act as nitrate reducing, azo dye reducing and butyrate producing, rendering the biofilm granules as a complete system suitable for textile wastewater bioremediation and ensure longevity of performance. Butyrate was produced by Bacillus subtilis under anaerobic fermentation (Rahimi et al. 2020). The spherical architecture proposed has been previously stated as an acceptable conceptual model for aggregates used in bioremediation under different oxygen levels (Aqeel et al. 2019). Fig. 10 represents the proposed model. This proposed model is currently the focus of undergoing investigation and work will be published soon.

\section{Conclusion}

Excessive discharge of nitrogen into the environment leads to interference with natural bioremediation processes. Azo dye containing wastewater treatment is specifically affected since both nitrates and azo 
dyes are electron acceptors, this results in an either/or situation when it comes to biodegradation. In our work, we studied the impact of nitrate on biofilm of nitrate reducing/azo dye reducing bacteria. Our results demonstrate that nitrate manipulates biofilm formation Bacillus sp. DN affecting the biofilm components. We can propose that Bacillus sp. can grow in thick biofilm composed of multi-bacterial layers, each would possess different oxygen levels that would induce a specific response. We propose for future work to utilize this modulation to obtain 3 biofilm layers, the outer "oxic" layer exposed to oxygen would activate the nitrate reduction, while the middle "microaerophilic" layer containing moderate oxygen would be responsible for dye reduction, finally, the inner "anoxic" layer with limited oxygen would be responsible for biopolymer production (preliminary data obtained), this would provide protection and sustainability for the granular biofilm. In addition to the formation of biofilm granules for nitrate and azo dye removal, the proposed granular model can be used in other biofilm-based applications such as bioelectrochemical systems or biofilm-based reactors.

\section{Declarations}

Funding: No available Funding source

Conflict of interest/competing interests: We declare no conflict of interest

Availability of data and material: The authors are ready to share any data upon request

Code availability: not applicable

Author's contribution: Ola M. Gomaa, Conceptualization, project administration, writing original draft and investigation, Nabila Selim Conceptualization, writing original draft and investigation, Hussein Abd El Kareem supervision.

\section{References}

1. Allkja J, Bjarnsholt T, Coenye T, Cos P, Fallarero A, Harrison J, Lopes S, Oliver A, Pereira MO, Ramage G, Shirtliff ME, Stoodley P, Webb JS, Zaat S, Goeres DM, Azevedo NF (2020) Minimum information guideline for spectrophotometric and fluorometric methods to assess biofilm formation in microplates. Biofilm 2:100010

2. Aqeel H, David G, Weissbrodt M, Cerruti GM, Wolfaardt B-M, Wilén, Steven N. Liss (2019) Drivers of bioaggregation from flocs to biofilms and granular sludge 2072. Environmental Science: Water Research Technology 5:2072-2089

3. Blasco F, Guigliarelli B, Magalon A et al. 2001. The coordination and function of the redox centres of the membrane-bound nitrate reductases. Cellular and Molecular Life Sciences: CMLS.58, 179-193. DOI: $10.1007 / \mathrm{pl00000846}$

4. Cirik K, Kitiş M, Çinar Ö (2013) Effect of nitrate on anaerobic azo dye reduction. Bioprocess Biosystem Engineering 36:69-79. doi:10.1007/s00449-012-0762-9. Epub 2012 Jul 27. PMID: 
22836282

5. Coelho C, \&Romão MJ (2015) Structural and mechanistic insights on nitrate reductases. Protein science: a publication of the Protein Society 24(12):1901-1911. https://doi.org/10.1002/pro.2801

6. Drake RR, Schwegler EE, Malik G, Diaz J, Block T, Mehta A, Semmes OJ (2006) Lectin capture strategies combined with mass spectrometry for the discovery of serum glycoprotein biomarkers. Mol Cell Proteomics.,5,1957-1967. doi: 10.1074/mcp.M600176-MCP200. Epub 2006 Jun 7. PMID: 16760258

7. Fabret C, Feher VA, Hoch JA (1999) Two-component signal transduction in Bacillus subtilis: how one organism sees its world. J Bacteriol 181(7):1975-1983. https://doi.org/10.1128/JB.181.7.19751983.1999

8. Gomaa OM, Fapetu S, Kyazze G, Keshavarz T (2017) The role of riboflavin in decolourisation of Congo red and bioelectricity production using Shewanella oneidensis-MR1 under MFC and non-MFC conditions. World J Microbioogy IBiotechnology 33:56. https://doi.org/10.1007/s11274-017-2223-8

9. Gomaa O, Selim NS, Linz JE (2013) Biochemical and Biophysical Response to Calcium Chloride Stress in Aspergillus niger and its Role in Malachite Green Degradation Cell Biochemistry and Biophysics. 65,413-423

10. Gieroba B, Krysa M, Wojtowicz K, Wiater A, Pleszczyńska M, Tomczyk M, Sroka-Bartnicka A (2020) The FT-IR and Raman Spectroscopies as Tools for Biofilm Characterization Created by Cariogenic Streptococci. Int J Mol Sci 21(11):3811. https://doi.org/10.3390/ijms21113811

11. Iyer VS, Hancock LE (2012) Deletion of $\sigma(54)(\mathrm{rpoN})$ alters the rate of autolysis and biofilm formation in Enterococcus faecalis. J Bacteriol 194:368-375. https://doi.org/10.1128/JB.06046-11

12. Karygianni L, Ren Z, Koo H, Thurnheer T (2020) Biofilm Matrixome: Extracellular Components in Structured Microbial Communities. Trends Microbiology 28:668-681. doi:10.1016/j.tim.2020.03.016. Epub 2020 Apr 21. PMID: 32663461

13. Kowalski MS, Devlin TR, Oleszkiewicz JA (2018) Start-up and long-term performance of anammox moving bed biofilm reactor seeded with granular biomass. Chemosphere 2018 Jun 200:481-486. DOI:10.1016/j.chemosphere.2018.02.130

14. Liu X, Wu X, Yang J (2010) Protein determination using methylene blue in a synchronous fluorescence technique. Talanta. 15;760-765. doi: 10.1016/j.talanta.2010.01.014. Epub 2010 Jan 18. PMID: 20298850

15. Lv P-L, Shi L-D, Dong Q-Y, Rittmann B, Zhao H-P (2020) How nitrate affects perchlorate reduction in a methane-based biofilm batch reactor. Water Res 171:115397. doi:10.1016/j.watres.2019.115397

16. Markx GH, Davey CL (1999) The dielectric properties of biological cells at radiofrequencies: Applications in biotechnology. Enzyme Microbial Technology 25:161-171

17. Mangalea MR, Plumley BA, Borlee BR (2017) Nitrate Sensing and Metabolism Inhibit Biofilm Formation in the Opportunistic Pathogen Burkholderiapseudomallei by Reducing the Intracellular Concentration of c-di-GMP. Frontiers in microbiology 8:1353. https://doi.org/10.3389/fmicb.2017.01353

Page $11 / 21$ 
18. Martín-Rodríguez AJ, Rhen M, Melican K, Richter-Dahlfors A (2020) Nitrate Metabolism Modulates Biosynthesis of Biofilm Components in Uropathogenic Escherichia coli and Acts as a Fitness Factor During Experimental Urinary Tract Infection. Frontiers in Microbiology 31:11:26. doi:10.3389/fmicb.2020.00026. PMID: 32082279; PMCID: PMC7005491

19. Pankratova G, Leech D, Gorton L, Hederstedt L (2018) Extracellular Electron Transfer by the GramPositive Bacterium Enterococcus faecalis. Biochemistry.57, 4597-4603. doi:

10.1021/acs.biochem.8b00600. Epub 2018 Jul 19. PMID: 29989403

20. Paquete, C 2020. Electroactivity across the cell wall of Gram-positive bacteria. Computational and Structural Biotechnology Journal, 18, 3796-3802

21. Pavlin M, Kanduser M, Reberšek M, Pucihar G, Hart FX, Magjarević R, Miklavčič, D.2005.Effect of Cell Electroporation on the Conductivity of a Cell Suspension. Biophys. J. 88, 4378-4390

22. Pethig R (1979) Dielectric and electronic properties of biological materials. Chichester, Wiley

23. Pamp SJ, Nielsen TT (2007) Multiple Roles of Biosurfactants in Structural Biofilm

24. Development by Pseudomonas aeruginosa. Journal of Bacteriology.189, 2531-2539

25. Rahimi S, Modin O, Roshanzamir F, Neissi A, Alam SS, Seelbinder B, Pandit S, Shi L, Mijakovic I (2020) Co-culturing Bacillus subtilis and wastewater microbial community in a bio-electrochemical system enhances denitrification and butyrate formation. Chem Eng J 397:125437

26. Remoundaki E, Kousi P, Joulian C, Battaglia-Brunet F, Hatzikioseyian A, Tsezos M (2008) Characterization, morphology and composition of biofilm and precipitates from a sulphate-reducing fixed-bed reactor. Journal of Hazardouz Material. 153(1-2):514 - 24. doi: 10.1016/j.jhazmat.2007.08.094. Epub 2007 Sep 4. PMID: 17931772

27. Selim NS, Desouky OM, Elbakrawy EM, Rezk AR (2010) Electrical behavior of stored erythrocytes after exposure to gamma radiation and the role of a-lipoic acid as radioprotector. Applied Radiation Isotopes 68:1018-1024

28. Sun Y, De Vos P, \&Heylen K (2016) Nitrous oxide emission by the non-denitrifying, nitrate ammonifier Bacillus licheniformis. BMC Genom 17:68. https://doi.org/10.1186/s12864-016-2382-2

29. Strola SA, Baritaux JC, Schultz E, Simon AC, Allier C, Espagnon I, Jary D, Dinten JM (2014) Single bacteria identification by Raman spectroscopy. Journal of Biomedical Optics. 19(11):111610. doi: 10.1117/1.JBO.19.11.111610. PMID: 25028774

30. Saravanan P, Jayachandran S2008. Preliminary characterization of exopolysaccharides produced by a marine biofilm-forming bacterium Pseudoalteromonas ruthenica (SBT 033)Letters in Applied Microbiology, 46, 1-6

31. Sarkar U, Dasgupta D, Bhattacharya T, Pal S, Chakroborty T (2010) Dynamic simulation of activated sludge based wastewater treatment processes: Case studies with Titagarh Sewage Treatment Plant. India Desalination 252:120-126

32. Shao Y, Zhang H, Buchanan I, Mohammed A, Liu Y (2019) Comparison of extracellular polymeric substance (EPS) in nitrification and nitritation bioreactors. Int Biodeterior Biodegradation 143:104713

Page $12 / 21$ 
33. Solanki K, Subramanian S, Basu S (2013) Microbial fuel cells for azo dye treatment with electricity generation: a review. Bioresource Technology.;131, 564 - 71. doi: 10.1016/j.biortech.2012.12.063. Epub 2013 Jan 5. PMID: 23403060

34. Stauch-White K, Srinivasan VN, Kuo-Dahab C, Park W, C., \& Butler CS (2017) The role of inorganic nitrogen in successful formation of granular biofilms for wastewater treatment that support cyanobacteria and bacteria. AMB Express 7(1):146. https://doi.org/10.1186/s13568-017-0444-8

35. Tugarova A, Scheludko A, Dyatloya Y, Fillipecheva Y, Kamney A (2017) FTIR spectroscopic study of biofilms formed by the rhizobacterium Azospirillumbrasilense Sp245 and itsmutant Azospirillumbrasilense Sp245.1610 Journal of Molecular structure, 142-147

36. Wringhton KC, Tharsh J,C, Melnyk RA, Bigi JP, Byne-Bailey KG, Remis JP, Schichnes D, Auer M, Chang CJ, Coates JD (2011) Evidence for direct electron transfer by a gram-positive bacterium isolated from microbial fuel cell. Applied Environmental Microbiology 77:7633-7639

\section{Figures}

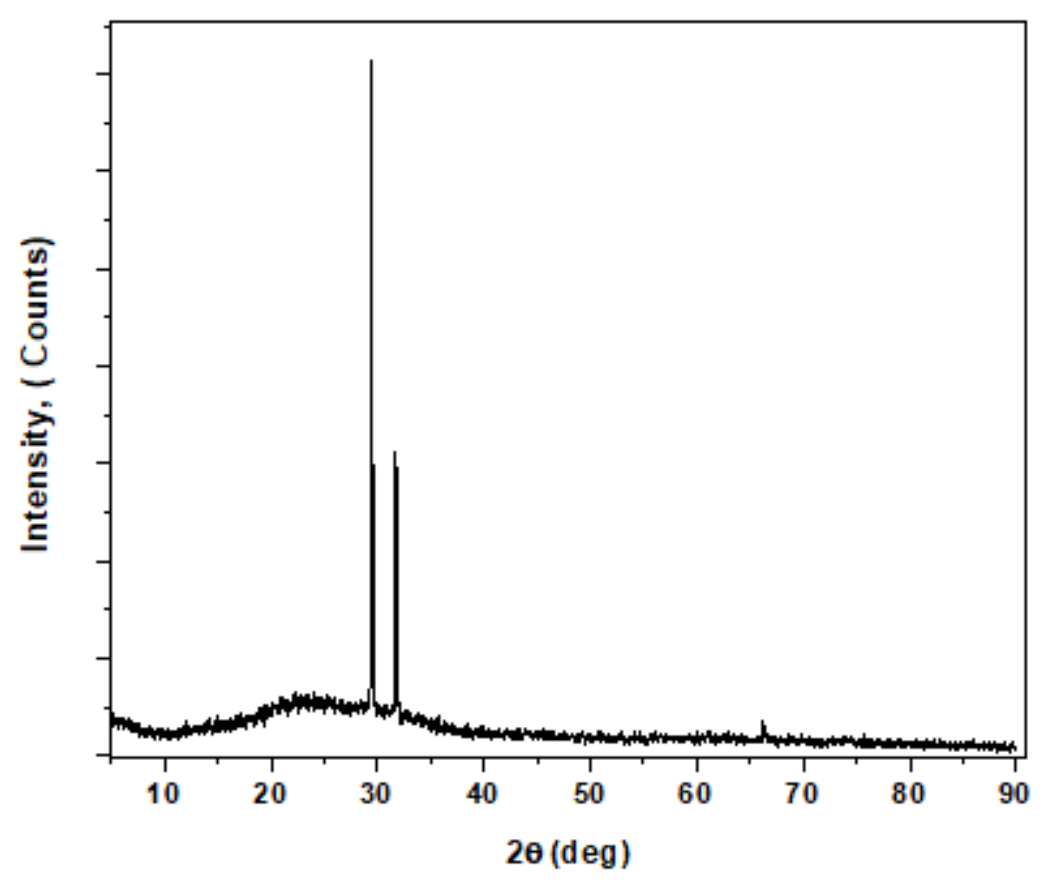

Figure 1

XRD for Bacillus sp. DN representing co-factors for nitrate reductase enzyme 


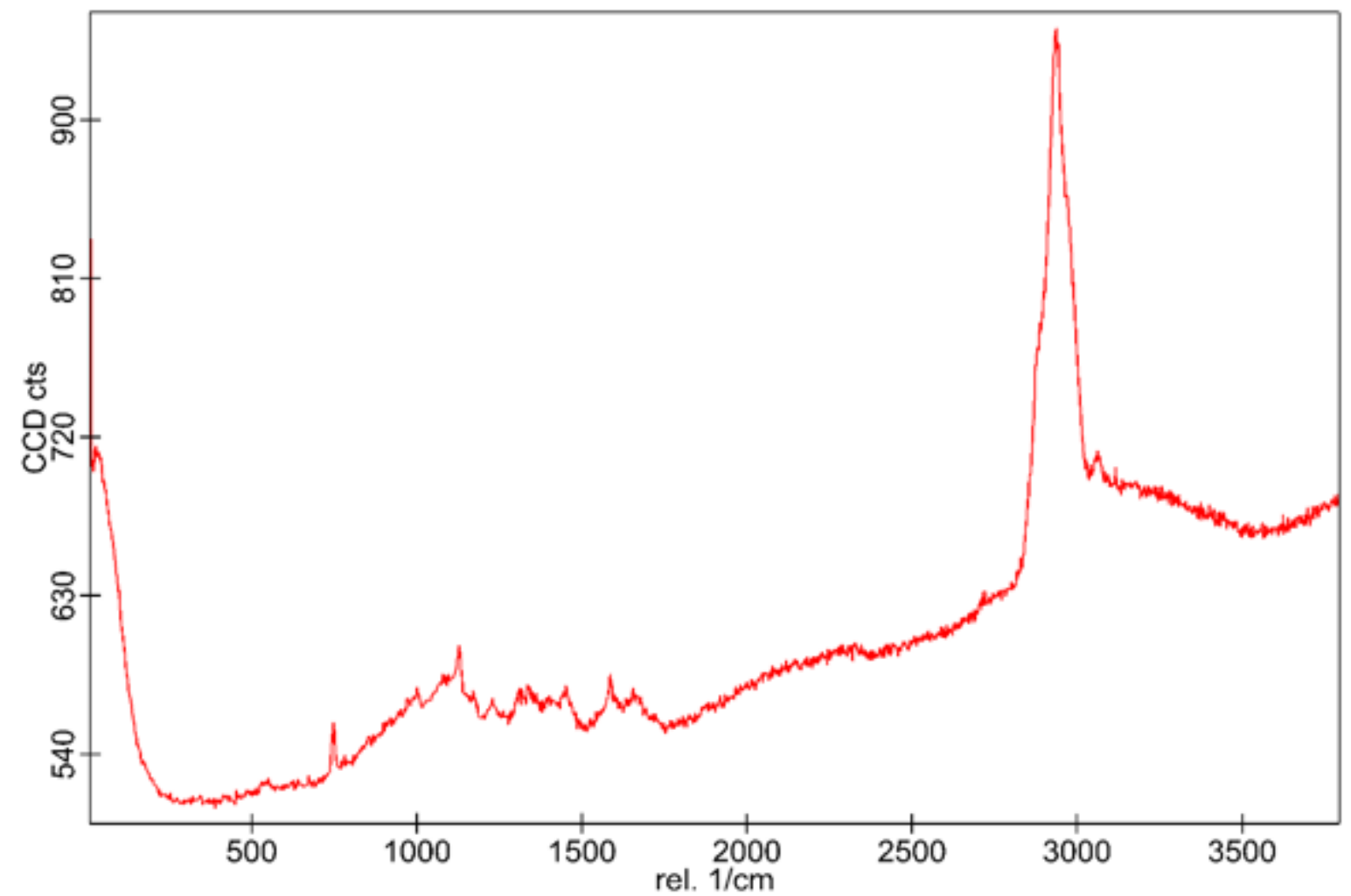

Figure 2

Confocal Raman Imaging for Bacillus sp. DN representing outer membrane cytochrome

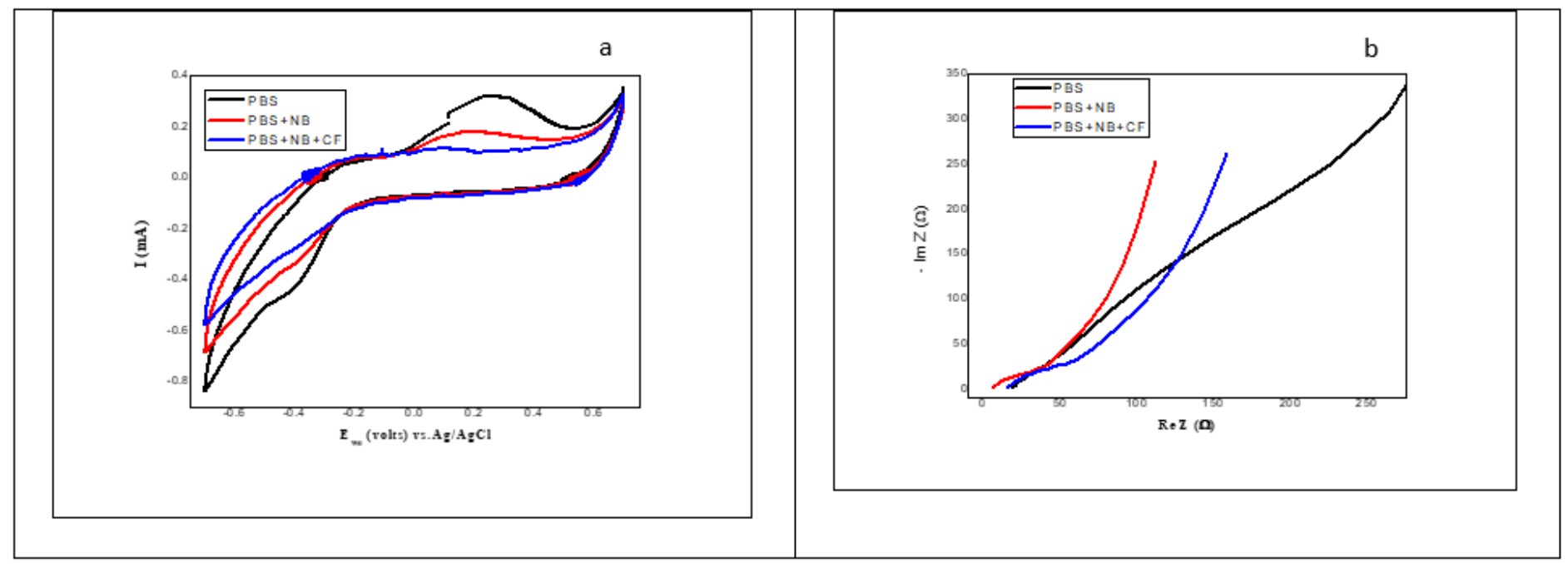

Figure 3

Cyclic voltamogram (a) and PEIS (b) for Bacillus sp. DN with and without its culture filtrate (CF) 


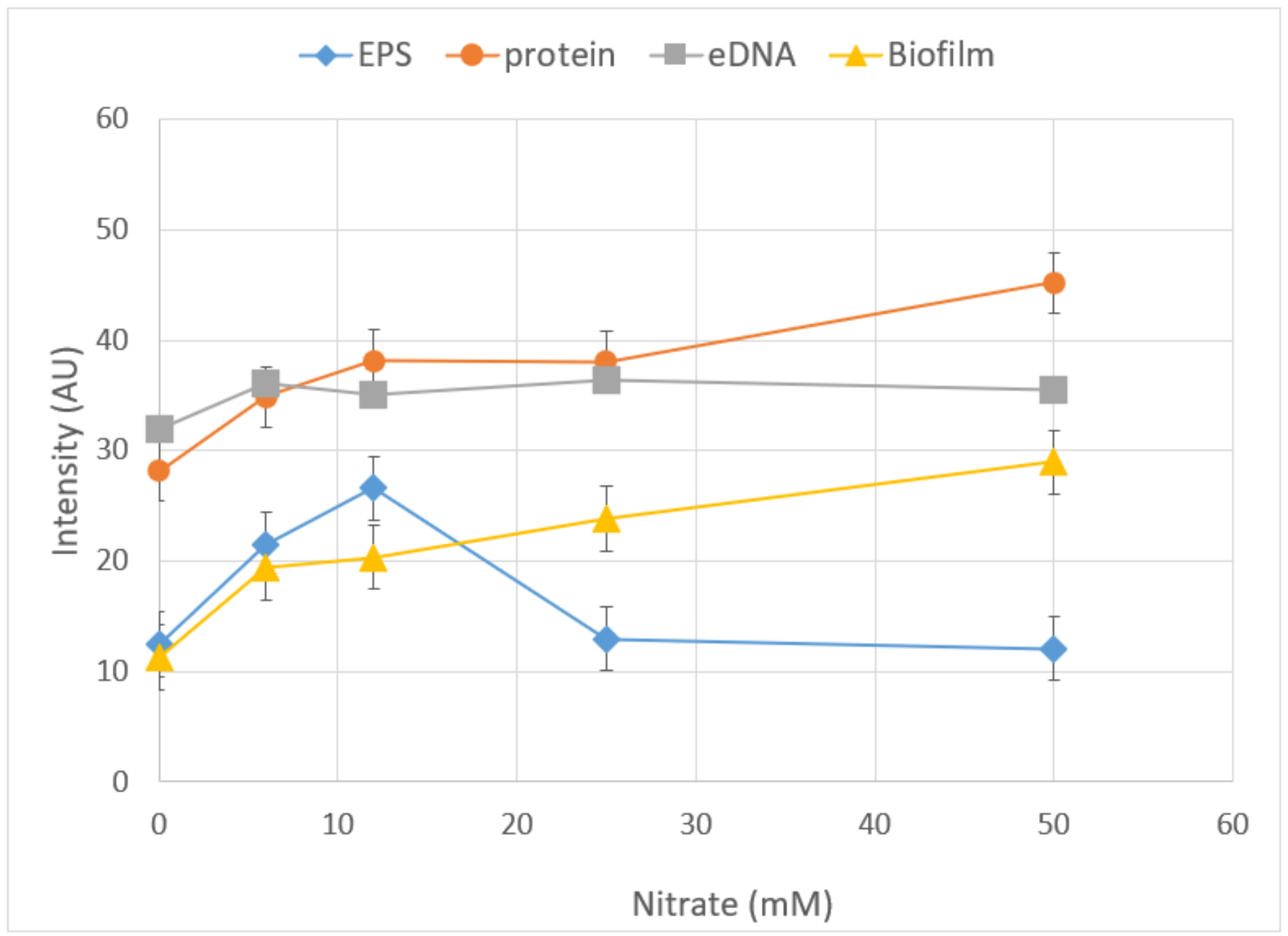

Figure 4

Assay for Bacillus sp. DN biofilmand its components in the presence of different nitrate concentrations 

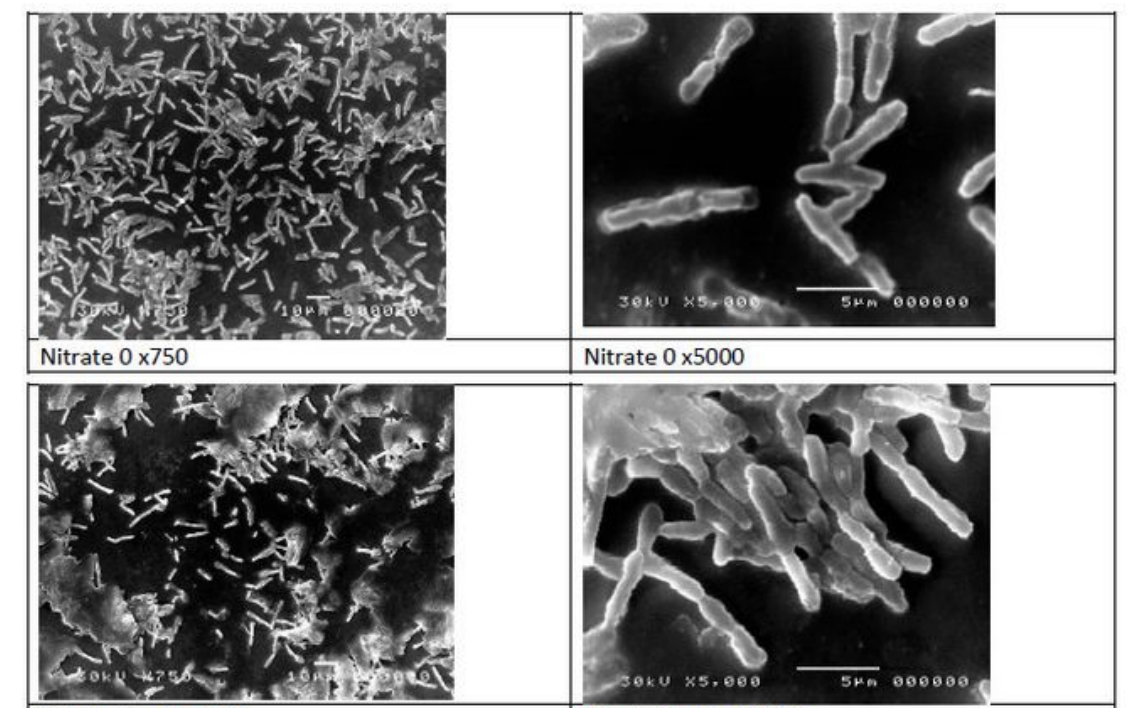

Nitrate $6 \mathrm{mM} \times 750$
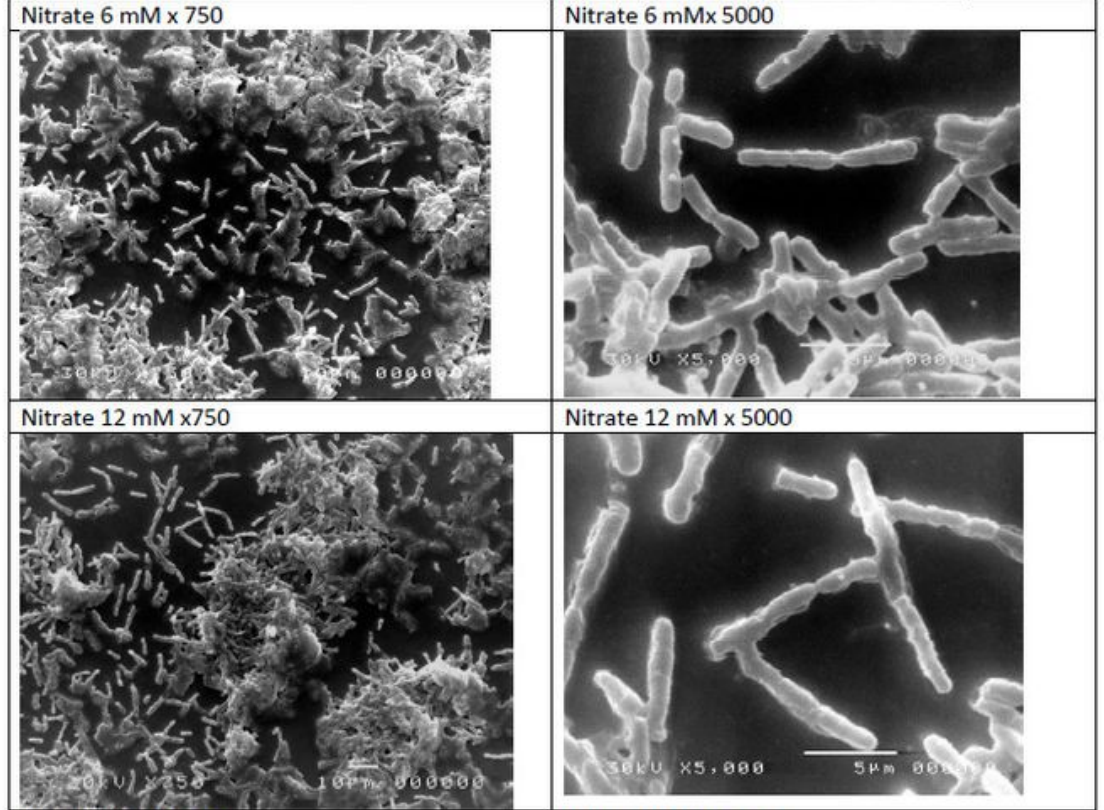

Nitrate $25 \mathrm{mM} \times 750$

Nitrate $12 \mathrm{mM} \times 5000$

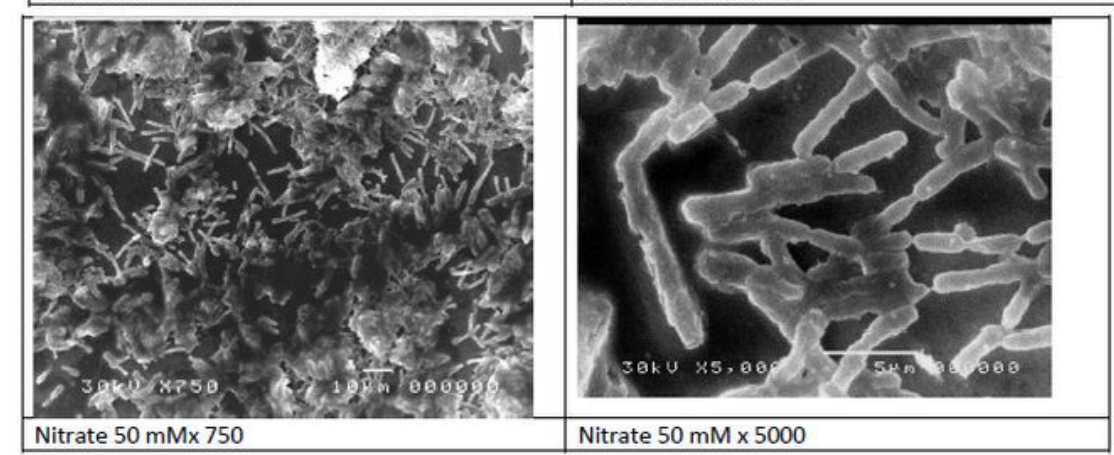

\section{Figure 5}

SEM images for Bacillus sp. DN grown under different nitrate concentrations 


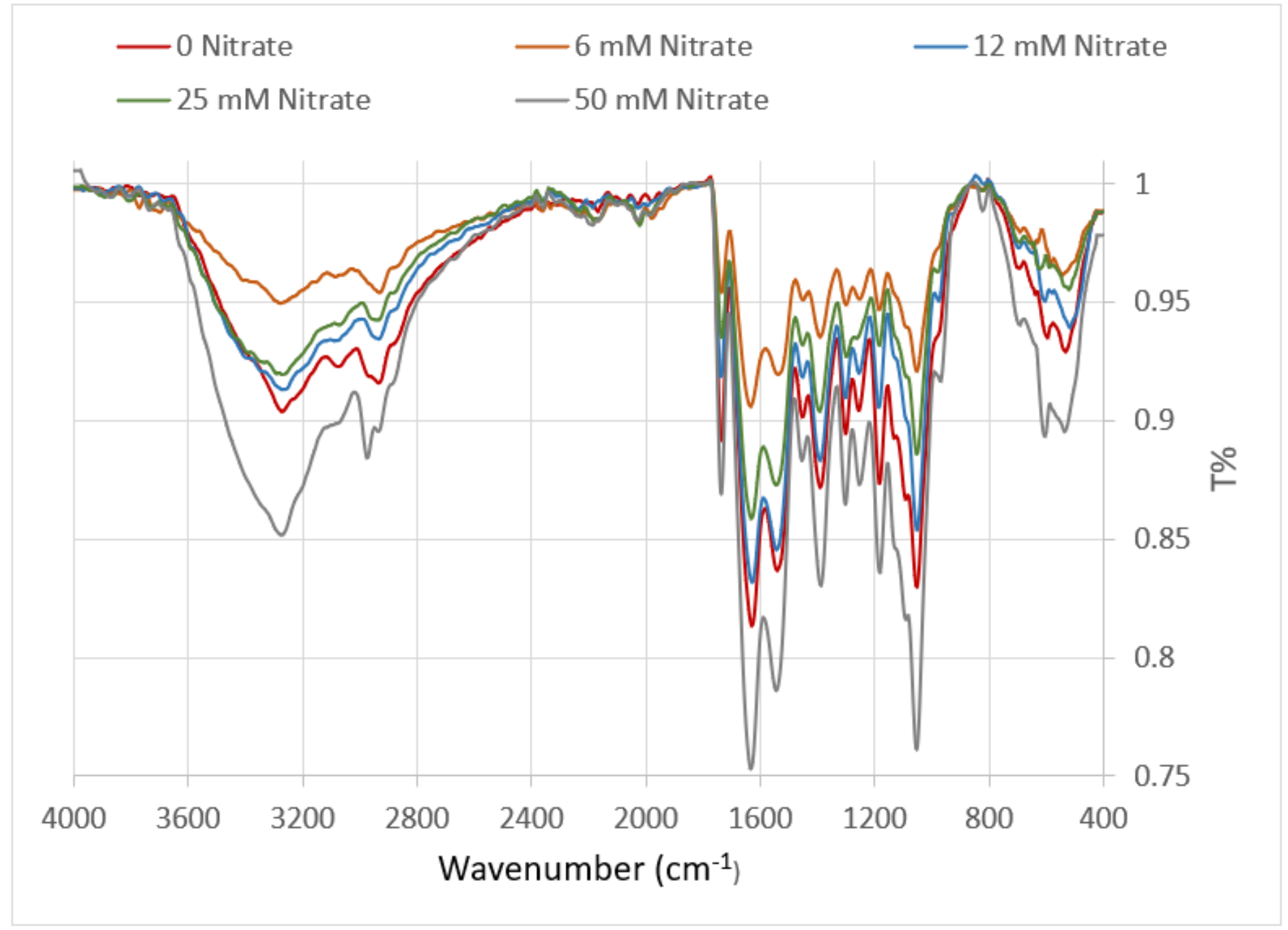

Figure 6

FTIR spectrum for Bacillus sp. DN grown in different nitrate concentrations 

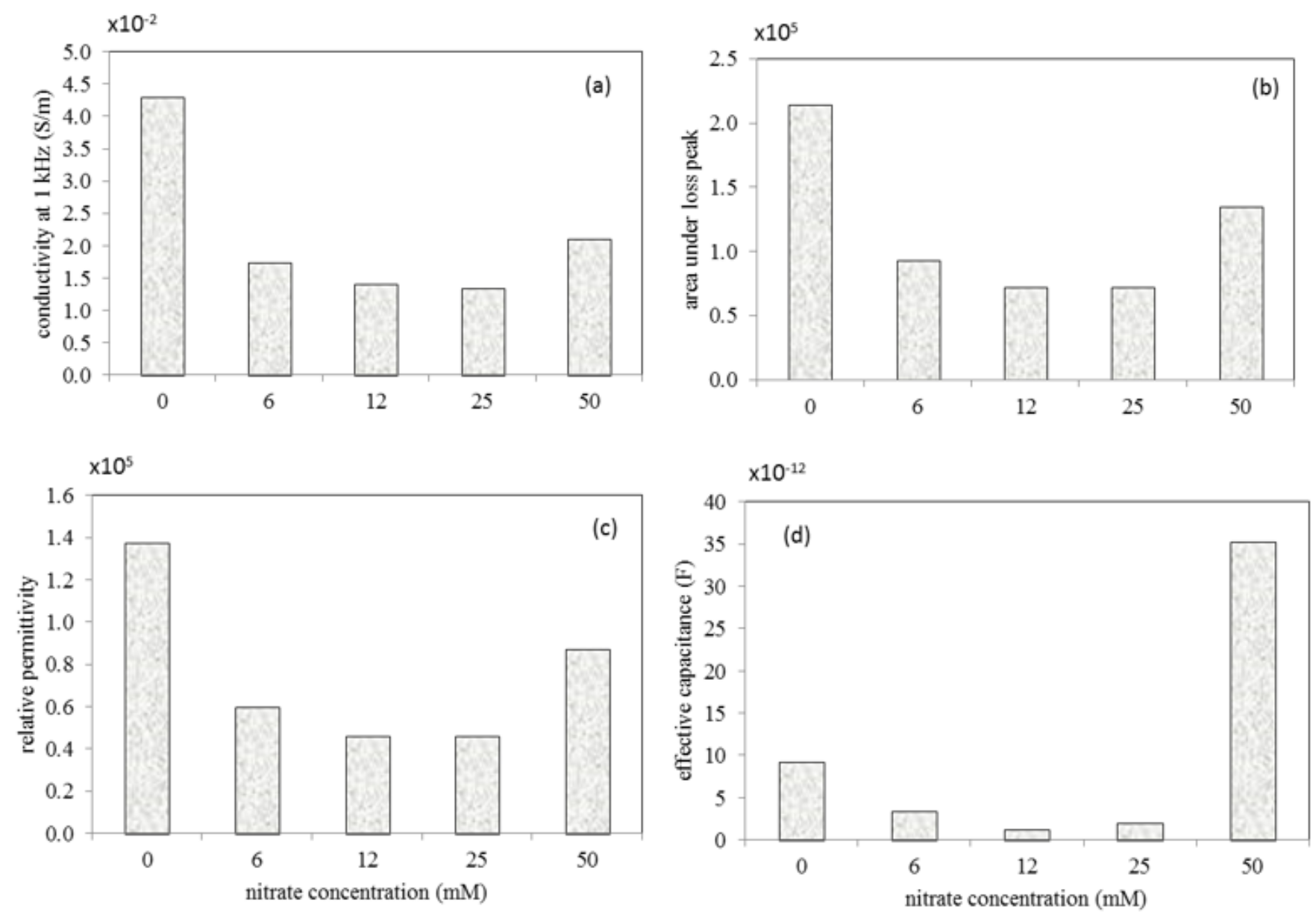

Figure 7

The conductivity at $1 \mathrm{kHz}(\mathrm{a})$, area under loss peak (b), relative permittivity (c) and membrane effective capacitance (d) for control and treated groups. 


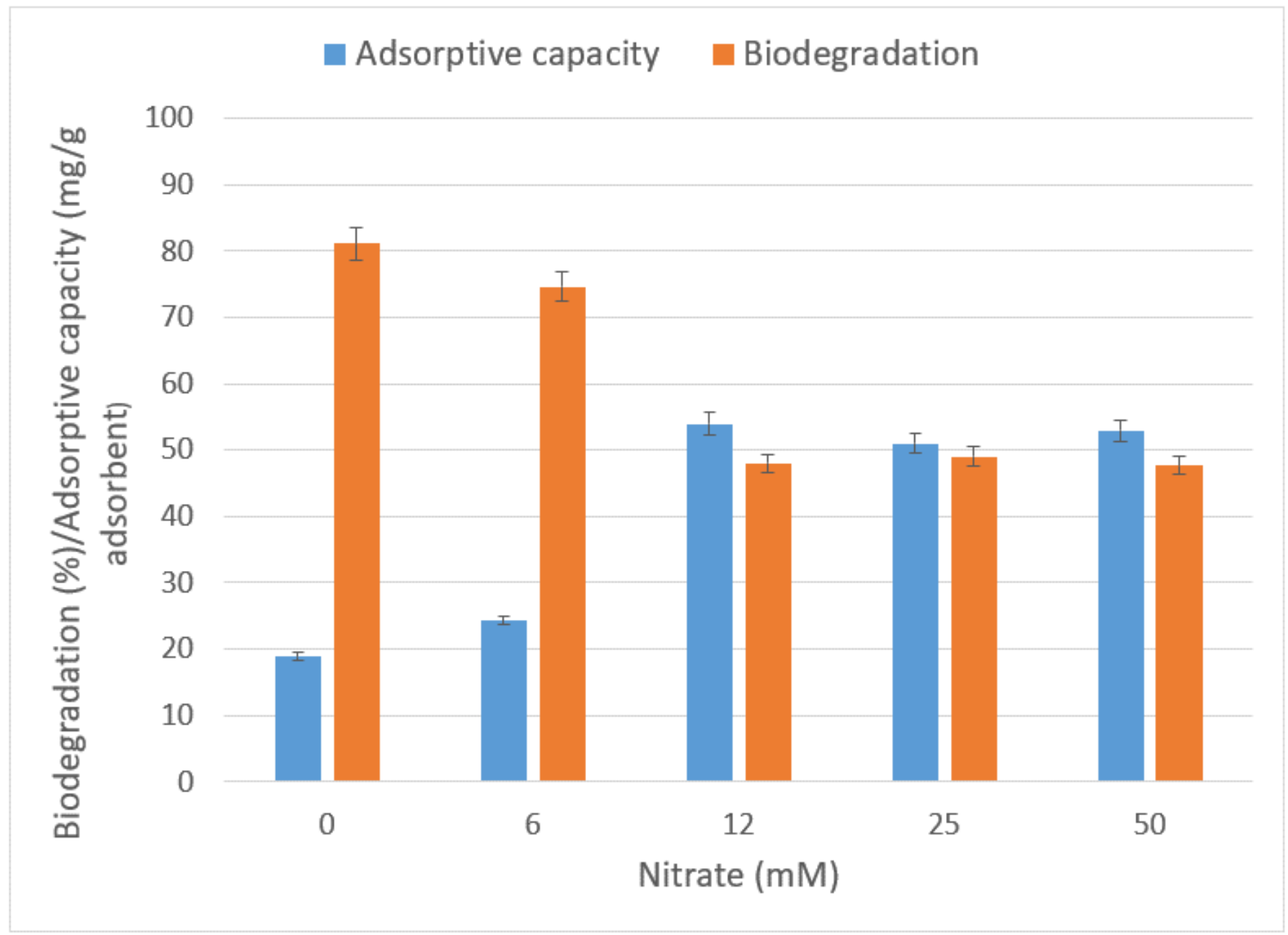

Figure 8

Congo red decolorization and adsorption in the presence of different nitrate concentration by Bacillus sp. DN 


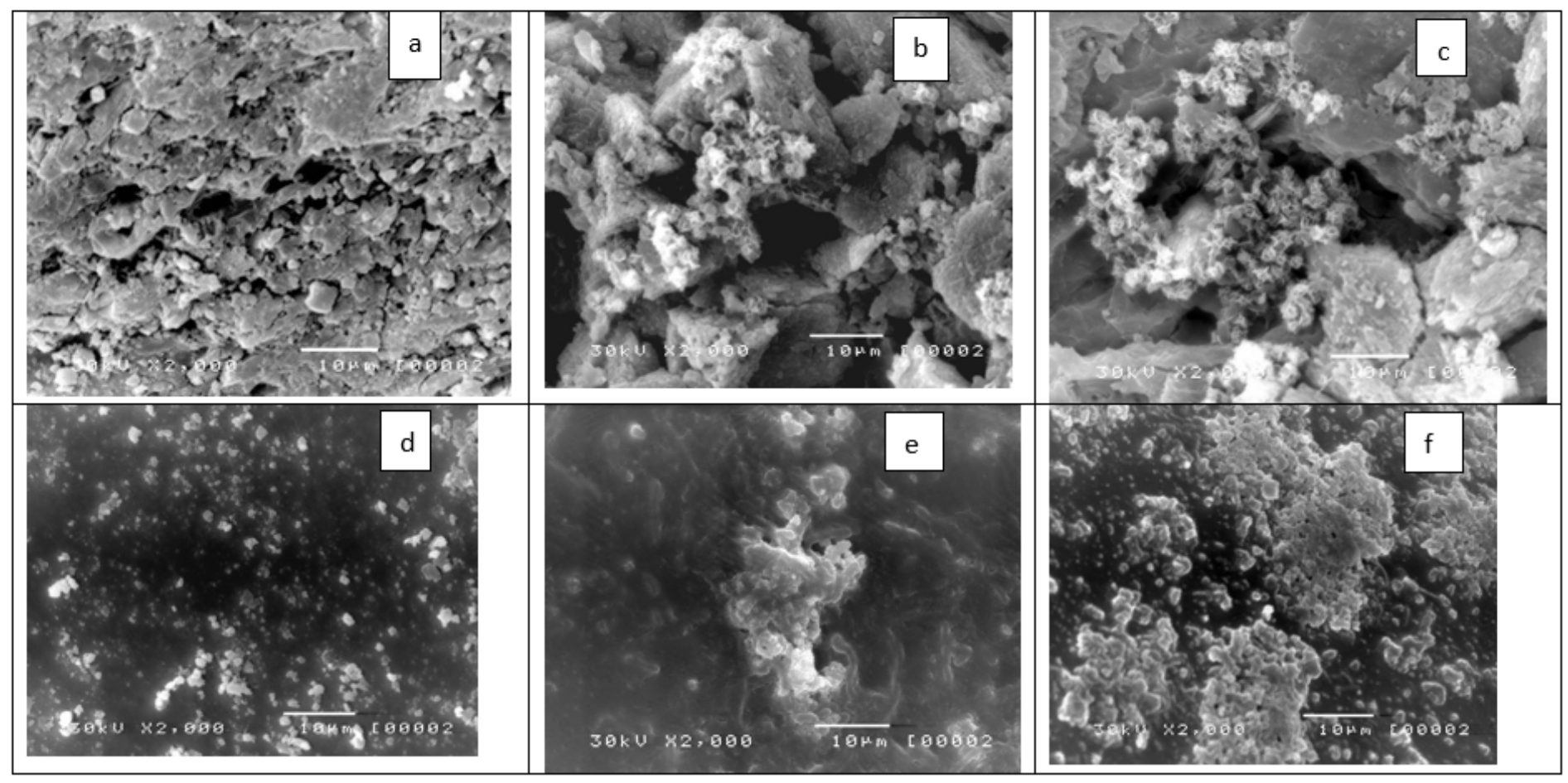

Figure 9

Granular Activated Carbon (GAC) before incubation with Bacillus sp. DN (a) and after $24 \mathrm{~h}$ incubation with the bacterium in the absence (b) and presence (c) of nitrate in the cultivation medium, Glass beads before incubation with Bacillus sp. DN (d) and after $24 \mathrm{~h}$ incubation with the bacterium in the absence (e) and presence $(f)$ of nitrate in the cultivation medium.

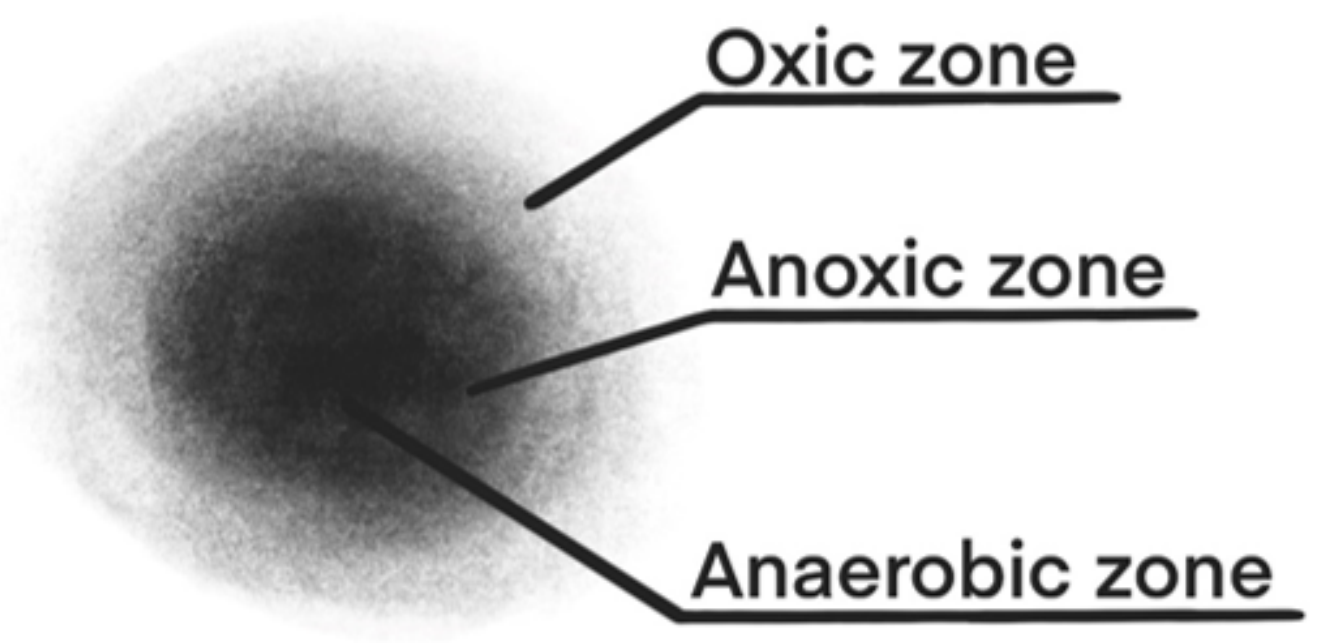

Figure 10

Proposed structure for biofilm carbon granules to be used in bioremediation of co-polluted wastewater 


\section{Supplementary Files}

This is a list of supplementary files associated with this preprint. Click to download.

- GraphicalabstractNitrates.pdf

- S1.pdf

- S2.pdf

- S3Therelativepermittivity.pdf 